\title{
Fatty acid hydroperoxides biotransformation by potato tuber cell-free extracts
}

\author{
Marie-Laure Fauconnier ${ }^{1}$, J erôme Delcarte ${ }^{2}$, Mondher Jaziri ${ }^{3}$, Patrick du Jardin ${ }^{4}$, Michel Marlier ${ }^{1}$ \\ ${ }^{1}$ Unité de Chimie Générale et Organique, Faculté Universitaire des Sciences Agronomiques, 2, Passage des Déportés, B-5030 Gembloux, Belgium \\ 2 Département de Génie rural, Centre de recherches agronomiques, 146, Chaussée de Namur, 5030 Gembloux, Belgium \\ ${ }^{3}$ Laboratoire de Biotechnologie Végétale, Université Libre de Bruxelles, Chaussée de Wavre 1850, B-1160 Bruxelles, Belgium \\ ${ }^{4}$ Unité de Biologie Végétale, Faculté Universitaire des Sciences Agronomiques, 2, Passage des Déportés, B-5030 Gembloux, Belgium
}

Received October 9, 2001 · Accepted April 24, 2002

\section{Summary}

Cleavage of 13-HPOD, 13-HPOT, 9-HPOD and 9-HPOT by potato tuber cell-free extracts was investigated. 13-HPOD and 13-HPOT enzymes were degraded almost completely while 9-HPOD and 9-HPOT were partially transformed. GC-MS analysis of the volatile compounds formed during the reactions revealed that $(Z)-3$ hexenal, $(E)-2$-hexenal, pentenols and dimers of pentene were obtained from 13-HPOT while from 13-HPOD hexanal and pentan-1-ol were formed. No volatile was found when 9-HPO isomers were used as substrate, but colneleic acid was produced. When Triton X-100 was omitted in the extraction buffer, only pentenols and dimers of pentene were identified from 13HPOT and pentan-1-ol from 13-HPOD. Our results reveal that potato tubers that contain Lox, which forms mainly 9-HPO, are able to metabolise the four HPO isomers. Moreover, 13-HPO cleaving activities are due to two distinct enzymatic systems based on, respectively, homolytic and heterolytic mechanisms. The fact that oxygenation of reaction medium dramatically decreases the amount of product resulting from homolytic cleavage strengthens the hypothesis of an anaerobic reaction due to Lox.

Key words: aldehyde - fatty acid hydroperoxide - heterolytic and homolytic hydroperoxide cleavage - hydroperoxide lyase - potato tuber - Solanum tuberosum $\mathrm{L}$.

Abbreviations: GC-MS = gas-chromatography mass spectrometry. $-\mathrm{HPLC}=$ high performance liquid chromatography. - HPO $=$ fatty acid hydroperoxide. $-13-\mathrm{HPOT}=13$ hydroperoxide of linolenic acid. $-13-\mathrm{HPOD}=13$ hydroperoxide of linoleic acid. $-9-\mathrm{HPOT}=9$ hydroperoxide of linolenic acid. 9-HPOD $=9$ hydroperoxide of linoleic acid. - Lox = lipoxygenase

\footnotetext{
* E-mail corresponding author: fauconnier.ml@sagx.ac.be
} 


\section{Introduction}

Depending on the plant source and on reaction conditions, plant Lox can form variable amounts of 13- and 9-HPOD/T. HPO can be degraded further by different enzymatic pathways, into various compounds involved in essential physiological roles in plants or responsible for the characteristic "green note» odour of plants and fruits (Blée 1998). Within the complex HPO-decomposing pathway, four main enzymatic activities are described: allene oxide synthase that forms precursors of $\alpha$ - and $\gamma$-ketols and jasmonic acid (Froehlich et al. 2001), peroxygenase and epoxygenase that cause epoxidation of HPO (Blée 1998), divinyl ether synthase that transforms HPO into fatty acid divinyl ethers (Hoyaux et al. 2001), and HPO lyase that cleaves HPO into aldehydes, alkanes or alcohols and oxo-acids (Delcarte et al. 2000).

In potato tubers, 9-HPO are mainly encountered as the major Lox isoform is a typical 9-Lox (Hugues et al. 2001). The following HPO decomposing activities have been described in potato: divinyl ether synthase (Weber et al. 1999), HPO lyase (Vancanneyt et al. 2001), peroxygenase and reductase that catalyse the synthesis of hydroxy octadi(tri)enoic acids (Göebel et al. 2001). Hamberg (1999) has also identified an epoxy alcohol synthase and epoxy alcohol hydrolase that transform HPO into trihydroxy octadecenoates or octadecadienoates.

The present study reports on the crude potato cell-free extract ability to transform exogenous 9-HPOD/T and 13-HPOD/ T. The metabolisation of HPO was followed by HPLC, while formed compounds were analysed by GC-MS or HPLC. We report here on the occurrence of an homolytic and an heterolytic cleavage activities of 13-HPO.

\section{Materials and Methods}

\section{Plant material}

Potato tubers (Solanum tuberosum L. cv. Bintje) were obtained from local market.

\section{Synthesis and analysis of HPO}

9-HPOD and 9-HPOT were synthesised using potato Lox while 13HPOD and 13-HPOT were formed by soybean Lox. The HPO was extracted and purified using C-18 microcolumns. The purity, controlled by HPLC, was higher than $95 \%$ for the four HPO (Fauconnier et al. 1997).

\section{Potato extracts}

$20 \mathrm{~g}$ of peeled potato tubers were homogenised in a warring blendor ( 3 times 30 seconds on ice) with $40 \mathrm{~mL}$ of sodium phosphate buffer (pH 6.7; $50 \mathrm{mmol} / \mathrm{L})$ containing EDTA $3 \mathrm{mmol} / \mathrm{L}$, DTT $3 \mathrm{mmol} / \mathrm{L}$ and when specified Triton X-100 0.2\% (W/V). The extract was centrifuged
(30 minutes, $4^{\circ} \mathrm{C}, 30,000 \mathrm{~g}$ ) and the supernatant was used directly as crude extract.

\section{UV determination of HPO metabolisation}

The determinations were performed with an Ultrospec 4000 UV-visible spectrophotometer (Pharmacia) at $234 \mathrm{~nm} .100 \mu \mathrm{L}$ of crude extract were added to $2.9 \mathrm{~mL}$ of sodium phosphate buffer $(50 \mathrm{mmol} / \mathrm{L}, \mathrm{pH} 7.5)$ containing the appropriate HPO $(0.04 \mathrm{mmol} / \mathrm{L}$ final concentration). Optimum reaction $\mathrm{pH}$ was determined by using sodium phosphate buffer $(50 \mathrm{mmol} / \mathrm{L}, \mathrm{pH}$ from 6.5 to 8.0$)$ and sodium borate buffer $(50 \mathrm{mmol} / \mathrm{L}$ from $\mathrm{pH} 8.0$ to 9.0 ). All the experiments were performed in triplicate and a control reaction was performed in the same conditions with a thermally denatured extract $\left(100^{\circ} \mathrm{C}, 5\right.$ minutes). The control reaction was systematically subtracted from the assays.

\section{Reaction conditions for HPLC determinations}

The appropriate HPO ( $5 \mathrm{mmol} / \mathrm{L}$ final concentration) was added to $2 \mathrm{~mL}$ of crude extract. The reaction was carried out, in triplicate, in sealed vials $\left(20^{\circ} \mathrm{C}, 15\right.$ minutes) under shaking. A control reaction was performed in the same conditions with a thermally denatured extract $\left(100^{\circ} \mathrm{C}, 5\right.$ minutes $)$.

\section{Oxygen effect}

Pure oxygen was bubbled during 5 minutes in $2 \mathrm{~mL}$ of crude extract containing Triton X-100 before addition of 13 -HPOT $(5 \mathrm{mmol} / \mathrm{L}$ final concentration). The reaction was carried out in triplicate in sealed vials $\left(20^{\circ} \mathrm{C}, 15\right.$ minutes) with shaking. A control reaction was performed in the same conditions with a thermally denatured extract $\left(100^{\circ} \mathrm{C}, 5\right.$ minutes).

\section{Determination of protein content}

Protein content was determined by the Kjeldahl method using a Tecator Kjeltec 1030 auto-analyser.

\section{HPLC determination of remaining HPO}

$300 \mu \mathrm{L}$ of methanol and $100 \mu \mathrm{L}$ of $22 \mathrm{mmol} / \mathrm{L}$ hexadienol (internal standard) were added to $100 \mu \mathrm{L}$ of reaction medium. $50 \mu \mathrm{L}$ of the resulting mixture were injected on an Inertsil 5 ODS 2 column of $250 \times 3 \mathrm{~mm}$ for HPLC analysis with UV detection at $234 \mathrm{~nm}$. Elution solvent $(0.5 \mathrm{~mL} / \mathrm{min})$ was water/acetonitile/sodium phosphate solution (20 mmol/L, pH 2 adjusted with $\mathrm{H}_{3} \mathrm{PO}_{4}$ ) 45/45/10. Identification of HPO was performed on the basis of retention time and UV spectrum by comparison with reference compounds synthesised, extracted and purified according to Fauconnier et al. (1997).

\section{Volatile compounds analysis}

The reaction medium $(2 \mathrm{~mL})$ was extracted twice with $2 \mathrm{~mL}$ of diethyl ether. The ethereal fractions were pooled and submitted to GC-MS analysis for identification (Delcarte et al. 2001). $1 \mu \mathrm{L}$ of ethereal extract was injected in a Hewlett-Packard HP5890 series II gas chromato- 
graph coupled to a HP5972 mass spectrometer. A HP-5MS $(30 \times 0.25 \mathrm{~mm}, 1 \mu \mathrm{m}$ film thickness) column was used with the following temperature program: from $35^{\circ} \mathrm{C}$ to $125^{\circ} \mathrm{C}\left(5^{\circ} \mathrm{C} / \mathrm{min}\right)$, then to $180^{\circ} \mathrm{C}$ $\left(25^{\circ} \mathrm{C} / \mathrm{min}\right)$.

Quantification of volatile products was performed by GC-FID analysis on a Hewlett-Packard HP6890 gas chromatograph with the same analytical conditions as with GC-MS analysis. Hexan-1-ol $(5 \mathrm{mmol} / \mathrm{L})$ was used as internal standard. Extraction yields were considered equal to $100 \%$ and response factor equal to 1 for all the compounds. The experiments were performed in triplicate.

\section{Colneleic and colnelenic acid analysis}

The $\mathrm{pH}$ of reaction medium $(2 \mathrm{~mL})$ was lowered to $\mathrm{pH} 3$ with $\mathrm{HCl} 6 \mathrm{~N}$ and extracted twice with $2 \mathrm{~mL}$ of diethyl ether. The ethereal fractions were pooled and evaporated under a $\mathrm{N}_{2}$ flow. The residue was dissolved in $100 \mu \mathrm{L}$ of acetonitrile. $100 \mu \mathrm{L}$ of a solution $(7 \mathrm{mmol} / \mathrm{L})$ of octadecadienoic acid conjugated (internal standard, Sigma O-5507) in acetonitrile was added. $50 \mu \mathrm{L}$ of the resulting mixture were injected on an Inertsil 5 ODS 2 column of $250 \times 3 \mathrm{~mm}$ for HPLC analysis with UV detection at $252 \mathrm{~nm}$. Elution solvent $(0.6 \mathrm{~mL} / \mathrm{min})$ was water $(0.01 \%$ V/V trifluoroacetic acid)/acetonitile (0.01\% V/V trifluoroacetic acid) $40 /$ 60 . The solvent gradient was: from $7 \mathrm{~min}$ to $30 \mathrm{~min}$ from $40 / 60$ to $28 / 72$, from $30 \mathrm{~min}$ to 34 minutes from $28 / 72$ to $0 / 100$. 0/100 was maintained until $45 \mathrm{~min}$. Identification of colneleic acid and colnelenic acid was performed on the basis of retention time and UV spectrum by comparison with reference compounds synthesised, extracted, purified by preparative HPLC, esterified with diazomethane and identified by GCMS analysis according to Galliard and Phillips 1972). The experiments were performed in triplicate.

\section{2-0x0-9Z-dodecenoic acid analysis}

Reaction media were pooled to obtain $10 \mathrm{~mL}$ and the $\mathrm{pH}$ was adjusted to 3 with $\mathrm{HCl} 6 \mathrm{~N}$. The reaction products were extracted on $\mathrm{C} 18$ cartridges (C18 Chromabond of $500 \mathrm{mg}$ from Machery-Nagel). The microcolumn was rinsed with $10 \mathrm{~mL}$ of water and eluated with $2 \mathrm{~mL}$ of methanol. The methanol was evaporated and the residue was redissolved in methanol. The compounds were reduced by an excess of $\mathrm{NaBH}_{4}$ under a $\mathrm{N}_{2}$ flow. After reaction, excess of $\mathrm{NaBH} 4$ was eliminated by $\mathrm{HCl} 0.1 \mathrm{~mol} / \mathrm{L}$. The reduced compounds were extracted on $\mathrm{C} 18$ cartridges as described before. The methanol was evaporated and the compounds were esterified by diazomethane. The ether was removed and the compounds were trimethylsilylated with BSTFA-TMCS in pyridine. GC-MS analysis was performed as described in Suurmeijer et al. 2000.

\section{Results and Discussion}

Cell-free extracts were prepared by grinding peeled potato tubers (cv. Bintje) in a buffer containing Triton X-100 as detergent. In a first attempt, the metabolisation of exogenous HPO was followed spectrophotometrically at $234 \mathrm{~nm}$. As shown in Table 1, the enzymatic metabolisation of HPO is more pronounced with the 13-HPO than with the 9-HPO, independent of the presence of Triton $\mathrm{X}-100$ in the extracts. Therefore, in order to allow the identification and the quantification of the
Table 1. Spectrophotometric determination of HPO metabolisation by potato tuber extracts (nmol of HPO degraded in one minute per mg of protein). Control reactions were performed with a thermally denatured extract. The results are the average of three determinations \pm standard deviations.

\begin{tabular}{lclll}
\hline & 13-HPOT & 13-HPOD & 9-HPOT & 9-HPOD \\
\hline $\begin{array}{l}\text { With Triton X-100 } \\
\left(\mathrm{nmol} \cdot \mathrm{mg} \mathrm{prot}^{-1} \cdot \mathrm{min}^{-1}\right)\end{array}$ & $14 \pm 3$ & $11 \pm 2$ & $5 \pm 1$ & $6 \pm 2$ \\
$\begin{array}{l}\text { Without Triton X-100 } \\
\left(\mathrm{nmol} \cdot \mathrm{mg} \mathrm{prot}^{-1} \cdot \mathrm{min}^{-1}\right)\end{array}$ & $16 \pm 3$ & $13 \pm 2$ & $7 \pm 2$ & $7 \pm 2$ \\
Control & 0 & 0 & 0 & 0 \\
\hline
\end{tabular}
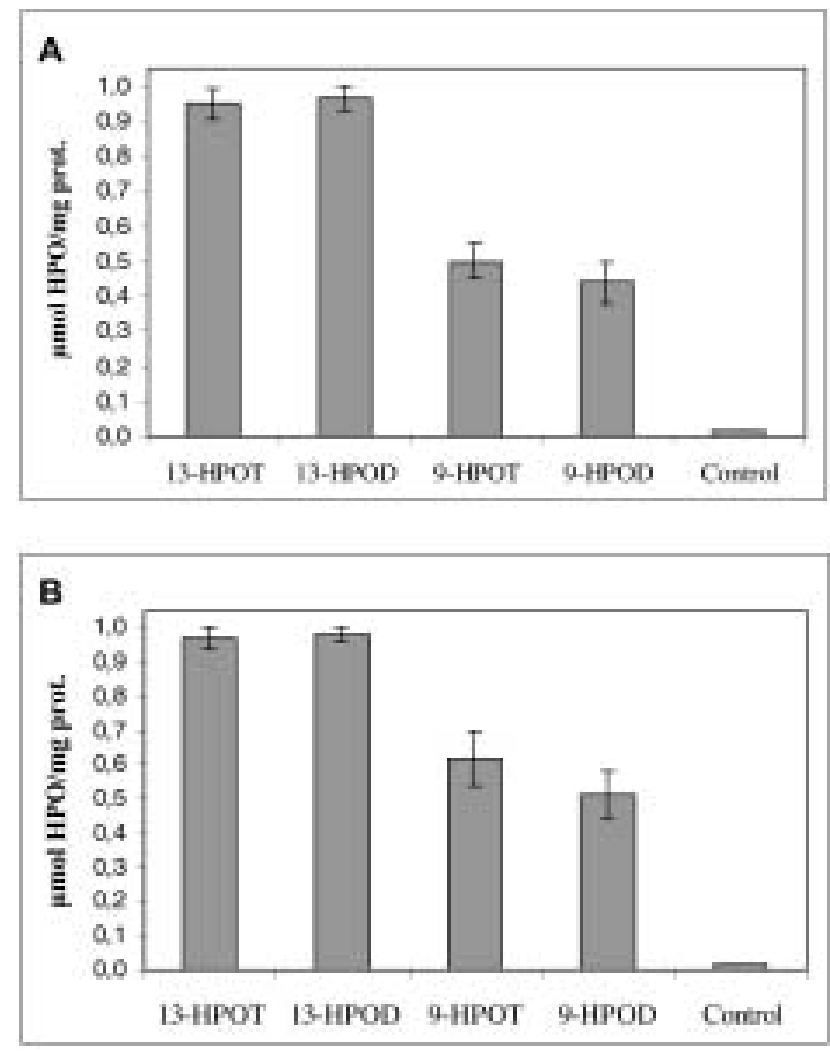

Figure 1. HPLC determination of HPO metabolisation by crude potato tuber extracts. A: with Triton X-100 in extraction buffer. B: without Triton $\mathrm{X}-100$ in the extraction buffer. Control reactions were performed with a thermally denatured extract. The results are the average of three determinations and standard deviations are shown on the figures.

formed products, the reactions were carried out for 15 minutes with higher substrate concentrations and the HPO metabolisation was followed by HPLC. Figure $1 \mathrm{~A}$ confirms that potato tuber cell-free extracts can metabolise the four HPO isomers. The 13-HPO isomers are almost completely transformed while 9-HPO isomers are only partially degraded after the 15 minutes of reaction. This last result is surprising as, in 
Table 2. GC-FID determination of volatile compounds formed by the reaction of potato tuber extracts on HPO (nmol/mg prot.). Control reactions were performed with a thermally denatured extract. /: no volatile compound detected. The results are the average of three determinations \pm standard deviations.

\begin{tabular}{|c|c|c|c|c|c|c|}
\hline & 13-НPOT & & 13-HPOD & & 9-HPOT & 9-HPOD \\
\hline $\begin{array}{l}\text { With } \\
\text { Triton X-100 }\end{array}$ & $\begin{array}{l}(Z) \text {-3 hexenal } \\
(E) \text {-2-hexenal } \\
\text { 1-penten-3-ol } \\
\text { 2-penten-1-ol } \\
\text { dimers of pentene (total) }\end{array}$ & $\begin{array}{r}172 \pm 24 \\
42 \pm 8 \\
54 \pm 10 \\
62 \pm 12 \\
22 \pm 5\end{array}$ & $\begin{array}{l}\text { Hexanal } \\
\text { pentan-1-ol }\end{array}$ & $\begin{array}{r}160 \pm 26 \\
69 \pm 15\end{array}$ & I & I \\
\hline $\begin{array}{l}\text { Without } \\
\text { Triton X-100 }\end{array}$ & $\begin{array}{l}\text { 1-penten-3-ol } \\
2 \text {-penten-1-ol } \\
\text { dimers of pentene (total) }\end{array}$ & $\begin{array}{l}49 \pm 12 \\
55 \pm 14 \\
20 \pm 5\end{array}$ & pentan-1-ol & $63 \pm 12$ & I & I \\
\hline Control & I & & I & & I & I \\
\hline
\end{tabular}

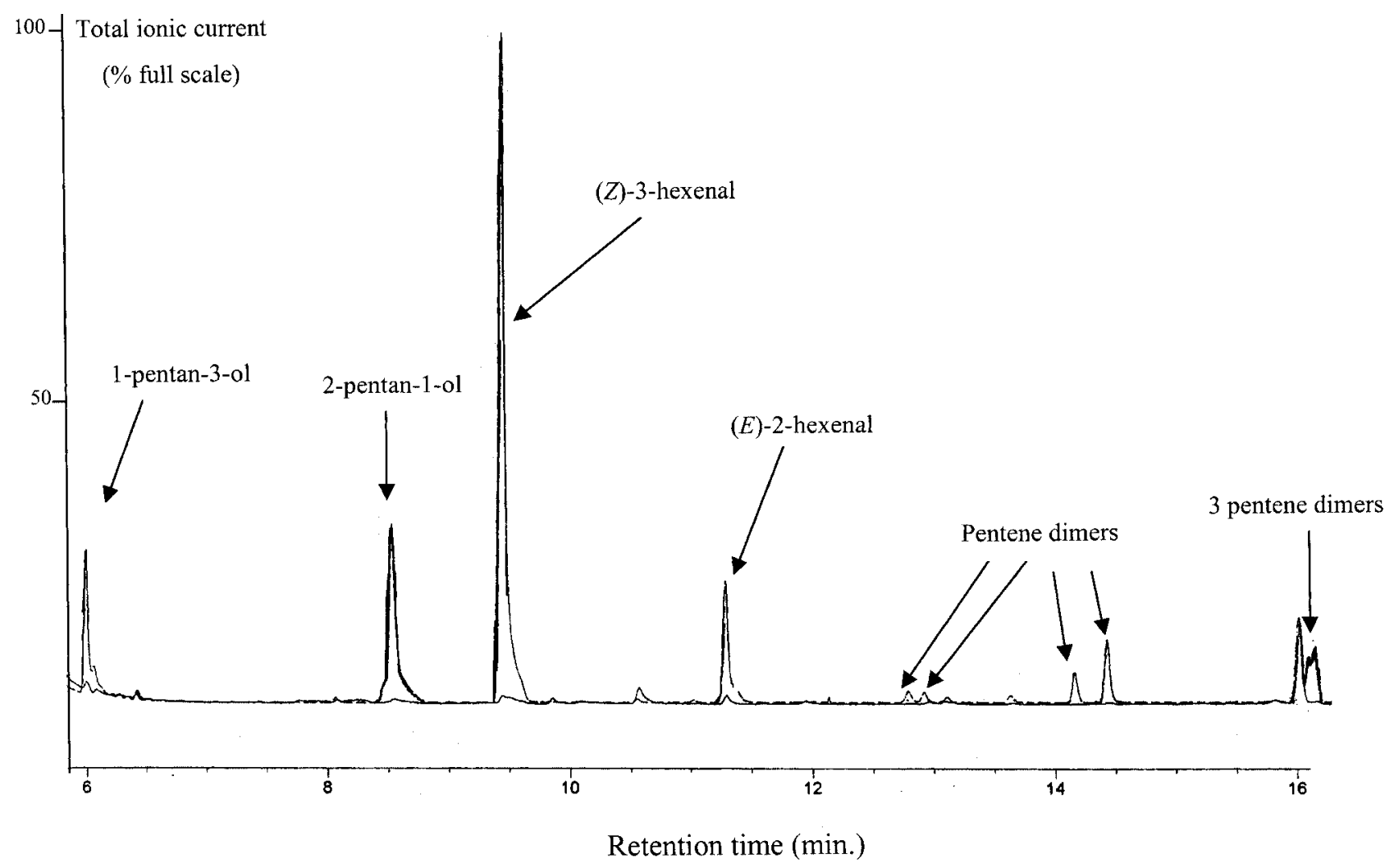

Figure 2. GC-MS chromatogram of volatile compounds formed by the reaction of a crude potato tuber extract containing Triton X-100 on $13-$ HPOT.

potato tubers, $95 \%$ of HPO formed by Lox are 9-isomers (Hugues et al. 2001). The enzymatic nature of the reaction was confirmed by performing the experiments in the same conditions with a crude extract that was thermally denatured. In those conditions, no HPO decomposition was observed.

Very similar results were observed with a Triton X-100-free extract (Fig. 1B) indicating that soluble enzymes are mainly responsible for the HPO decomposing activities.
GC-MS identification and GC-FID determination of the volatile compounds formed (Table 2) revealed that when 9-HPOT/D were used as substrates, no volatiles were detected, whereas our analytical method is adapted for the detection of $\mathrm{C} 9$ aldehydes and alcohols that potentially can be formed. Further investigations on the metabolisation of 9-HPO (HPLC analysis) revealed that colneleic acid was formed from 9-HPOD $(0.12 \pm 0.02 \mu \mathrm{mol} / \mathrm{mg}$ prot $)$ in the Triton $\mathrm{X}-100$ con- 
taining extracts but no colnelenic acid could be detected from 9-HPOT and in the control assays.

When 13-HPOT was used as substrate, the following volatile compounds were identified: (Z)-3-hexenal, $(E)$-2-hexenal, 2-penten-1-ol, 1-penten-3-ol and seven isomers of dimers of pentene (Fig. 2, Table 2), while in the case of 13-HPOD, hexanal and pentan-1-ol were identified. Pentane, which could be expected in the homolytic cleavage of 13-HPOD, is coeluted with the solvent and is not detectable in our analytical conditions. No volatiles were identified when thermally denatured extracts were used. Moreover, in Triton X-100-free extracts, (Z)-3-hexenal, $(E)$-2-hexenal and hexanol were not detected.

(Z)-3-hexenal, $(E)$-2-hexenal and hexanal, respectively biosynthesised from 13-HPOT and 13-HPOD, are the main volatiles formed from the cleavage of 13-HPO. They are typical products of hydroperoxide lyase, a membrane-bound enzyme that cleaves C-18 HPO into C-6 and C-12 fragments (Fauconnier et al. 1997). The presence of HPO lyase was confirmed by GC-MS identification of 12-oxo-9Z-dodecenoic acid (C-12 fragment) in the reaction media obtained by reaction of Triton X-100 crude extracts on 13-HPOD and 13-HPOT.

Finding an HPO lyase that cleaves 13 HPO in a plant producing mainly 9-HPO is quite unexpected, but the phenomenon has been reported in tomato fruits (Fauconnier et al. 1997). On the other hand, dimers of pentene and C-5 alcohols result from the homolytic cleavage of HPO (Nunez et al. 2000). The amount of products formed by homolytic cleavage is less important than by heterolytic cleavage, but the former compounds are not negligible as, on a molar ratio basis, they represent $39 \%$ and $30 \%$ of the volatile formed from 13 -HPOT and 13-HPOD respectively. The homolytic cleavage of HPO is usually encountered in mushrooms and algae (Gardner 1991). In starfish oocytes, the homolytic cleavage of arachidonic acid hydroperoxide gives a C-7 hydroxyacid and C-13 aldehydes (Brash et al. 1991). Here are only a few reports of the occurrence of such enzymatic activities in higher plants, in olive oil (Angerosa et al. 1998) and in soybean (Kondo et al. 1995, Salch et al. 1995), but the enzyme responsible for their synthesis is still unknown. Nevertheless, as reported by

Table 3. GC-FID determination of volatile compounds formed by the reaction of potato tuber extracts containing Triton X-100 on 13-HPOT with or without oxygenation of reaction medium (nmol/mg prot.). Control reactions were performed with a thermally denatured extract. /: no volatile compound detected. The results are the average of three determinations \pm standard deviations.

\begin{tabular}{lll}
\hline & $\begin{array}{l}\text { Without oxygenation } \\
\text { of reaction medium }\end{array}$ & $\begin{array}{l}\text { With oxygenation of } \\
\text { reaction medium }\end{array}$ \\
\hline 1-pentan-3-ol & $54 \pm 10$ & $13 \pm 4$ \\
2-pentan-1-ol & $62 \pm 12$ & $14 \pm 4$ \\
Pentene dimers (total) & $22 \pm 5$ & $5 \pm 2$ \\
\hline
\end{tabular}

Kondo et al. 1995, a soluble form of HPO lyase could be responsible for such an homolytic activity. Or, as suggested by Salch et al. 1995, a secondary activity of Lox could explain the homolytic cleavage of HPO. This assumption was strengthened by the study of Nunez et al. (2000) on the microalgae species Chlorella. To confirm the hypothesis of Lox implication in the formation of C-5 fragments, further investigations were performed. GC-FID analysis of the volatile compounds formed was conducted with a reaction medium in which pure oxygen was bubbled before the addition of 13-HPOT. A clear decrease in the synthesis of C-5 compounds was observed as shown in Table 3.

In conclusion, our paper provides further support for the extreme complexity of the HPO metabolisation in higher plants. The study of the homolytic cleavage of HPO in higher plants would require further investigations to confirm the role of anaerobic Lox reaction and to understand the enzymatic mechanisms involved. The role of the formed compounds in plant metabolism would also be investigated. Moreover, it would be interesting to clarify the role of $13-\mathrm{HPO}$ cleaving activities in a plant forming mainly 9-HPO.

Acknowledgements. Marie-Laure Fauconnier, Mondher Jaziri and Jérôme Delcarte are respectively Postdoctoral Researcher, Research Associate and Research Fellow of the Fonds National de la Recherche Scientifique of Belgium.

\section{References}

Angerosa F, Camera L, d'Alessandro N, Mellerio G (1998) Characterization of seven new hydrocarbon compounds present in the aroma of virgin olive oils. J Agric Food Chem 46: 648-653

Blée E (1998) Phytooxylipins and plant defense reactions. Prog Lipid Res 37: 33-72

Brash AR, Hugues MA, Hawkins DJ, Boeglin EW, Song WC, Meijer L (1991) Allene oxide and aldehyde biosynthesis in Starfish Oocytes. J Biol Chem 266: 22926-22931

Delcarte J, Fauconnier ML, Hoyaux P, Jacques P, Thonart P, Marlier M (2000) Revue bibliographique: l'hydroperoxide lyase. Biotechnol Agron Soc Environ 4: 157-167

Delcarte J, Jacques P, Fauconnier ML, Hoyaux P, Matsui K, Marlier M, Thonart $P$ (2001) The homolytic and heterolytic fatty acid hydroperoxide lyase-like activities of hematin. Biochem Biophys Res Com 286: $28-32$

Fauconnier ML, Perez AG, Sanz C, Marlier M (1997) Purification and characterization of tomato leaf (Lycopersicon esculentum L.) hydroperoxide lyase. J Agric Food Chem 45: 4232-4236

Froehlich JE, Itoh A, Howe GA (2001) Tomato Allene oxide synthase and fatty acid hydroperoxide lyase, two cytochrome P450s involved in oxylipin metabolism, are targeted to different membranes of chloroplast envelope. Plant Physiol 125: 306-317

Galliard T, Phillips D (1972) The enzymic conversion of linoleic acid into 9-(nona 1',3'-dienoxy) non-8-enoic acid, a novel unsaturated ether derivative isolated from homogenates of Solanum tuberosum tubers. Biochem J 129: 743-753

Gardner HW (1991) Recent investigations into the lipoxygenase pathway. Biochim Biophys Acta 1084: 221-239 
Göebel C, Feussner I, Schimdt A, Scheel D, Sanchez-Serrano J, Hamberg M, Rosahl S (2001) Oxylipin profiling reveals the preferential stimulation of the 9-lipoxygenase pathway in elicitor-treated potato cells. J Biol Chem 276: 6267-6273

Hamberg M (1999) An epoxy alcohol synthase pathway in higher plants: biosynthesis of antifungal trihydroxy oxylipins in leaves of potato. Lipids 34: 1131-1142

Hoyaux P, Fauconnier ML, Delcarte J, du Jardin P, Marlier M (2001) Biotechnol. Agron. Soc. Environ. Synthèse bibliographique: la divinyl ether synthase de plantes 5: 79-84

Hugues RK, West S, Hornostaj AR, Lawson DM, Fairhurst SA, Sanchez RO, Hough P, Robinson BH, Casey R (2001) Probing a novel potato lipoxygenase with dual positional specificity reveals primary determinants of substrate binding and requirements for a surface hydrophobic loop and has implications for the role of lipoxygenases in tubers. Biochem J 353: 345-355

Kondo Y, Hashidoko Y, Mizutani J (1995) An enzymatic formation of 13-oxo-trideca-9, 11-dienoic acid from 13-hydroperxylinolenic acid by homolytic hydroperoxide lyase in elicitor-treated soybean cotyledons. Biochem Biophys Acta 1255: 9-15
Nunez A, Foglia T, Savary B, Piazza G (2000) Anaerobic lipoxygenase activity from Chlorella pyrenoidosa responsible for the cleavage of the 13-hydroperoxides of linoleic and linolenic acids. Eur J Lipid Sci Technol 102: 181-188

Salch YP, Grove MJ, Takamura H, Gardner HW (1995) Characterization of a C-5, 13-cleaving enzyme of 13-(S)-hydroperoxide of linolenic acid by soybean seed. Plant Physiol 108: 1211-1218

Suurmeijer CNSP, Perez-Gilabert M, Van Unen DJ, Vander Hijden HTWM, Veldink GA, Vliegenthart JFG (2000) Purification, stabilization and characterization of tomato fatty acid hydroperoxide lyase. Phytochem 53: 177-185

Vancanneyt G, Sanz C, Farmaki T, Paneque M, Ortego F, Castanera P, Sanchez-Serrano JJ (2001) Hydroperoxide lyase depletion in transgenic potato plants leads to an increase in aphid performance. Proc Natl Acad Sci USA 98: 8139-8144

Weber H, Chételat A, Caldelari D, Farmer EE (1999) Divinyl ether fatty acid synthesis in late blight-diseased potato leaves. Plant Cell 11: 485-493 